\title{
Features of Forming Students' Reflective Position While Studying Mathematics at University by Means of Information and Communication Technologies
}

\author{
Aliya V. Konysheva ${ }^{{ }^{*}}{ }^{\text {, Svetlana E. Chirkina }}{ }^{2}$, Dinara G. Vasbieva ${ }^{3}$ \\ ${ }^{1}$ Vyatka State University, Kirov, RUSSIA \\ ${ }^{2}$ Kazan (Volga region) Federal University, Kazan, RUSSIA \\ ${ }^{3}$ Financial University under the Government of the Russian Federation, Moscow, RUSSIA
}

Received 29 July 2018 - Revised 22 November 2018 - Accepted 2 January 2019

\begin{abstract}
Modern professional education takes into account the didactic potential of disciplines and modern educational technologies while searching, developing and implementing new resources and mechanisms in the process of preparing a competitive creative personality with the need for continuous self-improvement and self-development. Studying and analyzing the multicomponent composition of professional training, researchers note the pedagogical potential of information and communication technologies and mathematical disciplines as well as skills of self-determination, selforganization and reflection in the process of forming professional competence. Thus, the purpose of the article is to study features of forming students' reflective position while studying mathematics at university by means of information and communication technologies. The leading method is the design of a methodical system for teaching mathematics at university, including didactic tools which contribute to increasing students' interest to the subject, as well as the development of skills in selfdetermination, self-organization and self-analysis. As a result of the research, the authors of the article defined the didactic potential of information and communication technologies in the process of forming students' reflective position while studying mathematics. They pointed out methodical aspects of including various forms of interaction of subjects of the educational process while studying mathematics at university through the use of information and communication technologies. Moreover, the authors developed the method "I am learning myself" in order to form students' reflective position.
\end{abstract}

Keywords: studying mathematics at university, mathematical training, reflexive position, forming reflective position, information and communication technologies

\section{INTRODUCTION}

One of the main directions in the teaching of mathematics at university is the realization of a personality-oriented approach. It is due to the fact that recognition of the priority of the student's individuality and self-worth, the maximum appeal to his individual experience, the need for self-organization, self-determination and selfdevelopment contribute to the formation of a competitive personality (Oborsky et al., 2018; Zaitseva et al., 2017). An interesting aspect is the modern aspect of this issue realized through the introduction of information and communication technologies into the educational practice (Kvon et al., 2017, 2018). This allows us to consider the process of students' mathematical preparation at university from the standpoint of ideas of dialogue, subjectivity and individuality. Comprehension of the foregoing contributed not only to the presentation of the content of training in the form of different-level personality-oriented tasks, the creation of conditions for equal cooperation between the teacher and the student, but also to the development of the student's independence and activity, the

(C) 2019 by the authors; licensee Modestum Ltd., UK. This article is an open access article distributed under the terms and conditions of the Creative Commons Attribution License (http://creativecommons.org/licenses/by/4.0/).

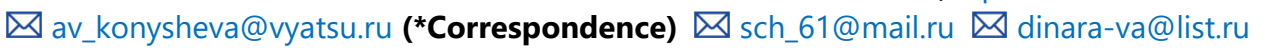




\section{Contribution of this paper to the literature}

- The authors developed a unified methodical system, including the stages of teaching mathematics at university, coupled with various forms of interaction between subjects of the educational process through information and communication technologies.

- They developed the method "I am learning myself" which aims to form students' reflective position in the process of studying mathematics.

- The authors discovered the potential of information and communication technologies in shaping students' reflective position through the implementation of the methodology "I am learning myself".

formation of their reflective position. By "reflection" we mean a certain ability of the subject to self-organization, self-development and, consequently, to self-improvement. Formation of the student's reflective position is defined as the process of developing their reflective abilities, skills and skills (Ishkov, 2004). Understanding and controlling their actions, making an informed choice and predicting the result, the subjects learn to build their activities. Note that the reflective component is significant in the structure of students' readiness for professional activity. It is characterized by the following parameters: knowledge and ability to use methods of implementation of monitoring and evaluation activities in practice; high self-esteem of their own skills; confidence in using theoretical knowledge in solving applied problems, planning skills, organization and correction of educational and cognitive activity.

It should be emphasized that deep and intensified individualization of the educational process is achieved thanks to the didactic potential of information and communication technologies. First of all, it is explained by their polyfunctionality. In particular, the use of information and communication technologies in teaching mathematics makes it possible to take into account students' individual characteristics through the formation and implementation of individual educational trajectories, provides feedback between subjects of the educational process; contributes to the creation of stimulating situations (success situations, introduction of competitive elements, etc.), provides an atmosphere of cooperation and interaction. The foregoing determines the appropriateness of considering the issue of the pedagogical potential of information and communication technologies in shaping students' reflective position.

Thus, the purpose of the presented research is to determine methodological features of including information and communication technologies in the process of teaching mathematics in order to form a reflective position, and also to design a methodical system for teaching mathematics using information and communication technologies based on the revealed aspects.

\section{LITERATURE REVIEW}

The review of scientific, pedagogical and methodological literature allowed to distinguish three aspects which are of greatest interest for the research: the issues of forming students' reflective position at university, the methodological system of teaching mathematics as a condition for forming students' reflective position at university; pedagogical potential of information and communication technologies in this process.

Note that the problem of forming a reflective position of the subjects of the educational process is actively developed by foreign and our researchers. The basic research is the work of Wulfov and Harkin (1995), which reveals the phenomenon of reflexion as a pedagogical process. Rath (2010) emphasizes that the formation of student's reflective position is a key condition for their successful education and subsequent professional implementation. It is pointed out that the process of forming a reflective position and reflexive thinking in general should be conditioned by following principles: the personal orientation of the educational process (individualization); its contextuality and the subjective nature of it. In this connection, the work of Khusainova, Chirkina and Gabdrakhmanova (2015) is also very important. It reveals the issue of the influence of the individual educational trajectory on forming a competitive personality.

Issues related to the study of psychological and technological foundations of forming the reflective position of subjects of the educational process are debatable and deserve special attention (Biktagirova \& Valeeva, 2014; Lin, Hmelo \& Kinzer, 1999; Semenov, 2011). In particular, pedagogical science lacks a unified approach to the formation of students' reflective position. It is mainly determined by the variety of didactic and technological means. Lin., Hmelo, and Kinzer (1999), note that pedagogically based technology plays a significant role in the development and support of students' reflection. At the same time, an important condition is the implementation of a systematic approach in organizing the process of teaching students.

We consider information and communication technologies as the main didactic toolkit in the process of forming reflective position. Specificity of the educational process with the introduction of new technologies is presented in works of Nelson (2007), Dede (2008), Kubiatko et al. (2010), Baytak et al. (2012), Geiger et al. (2016). These studies are interesting as the authors describe in detail the process of the influence of digital technologies on the 
components of the pedagogical process, the cognitive structure of the personality, its professional development. In addition, it should be noted that this problem is studied from the point of improving mathematical education.

The works of Wang and Lin (2008) and Yuen (2011) explore the factors which influence the formation of reflexive thinking and a reflective position. In particular, the research of Yuen (2011) indicates the effectiveness of problem training in the process of forming students' reflective thinking. This approach to the problem allowed to define a system of problematic tasks - as a key condition in forming the reflective position of subjects of the educational process.

The pedagogical potential of the new toolkit in the formation of a competitive specialist with high readiness for professional activity is described by Ryan (2015). In this issue, the key thing is the problem of forming a reflective position. The author singled out a unified principle of realization of the task - the principle of integration and controllability. This approach allows to combine the content, technological, intellectual resources of the educational process, the functioning of which ensures the process of forming students' reflective position.

We have analyzed issues in domestic pedagogical theory and practice related to the use of the pedagogical potential of educational disciplines in the process of forming students' reflective position (Bagdai, 2007) and issues which reveal pedagogical support and possibilities of using interactive teaching technologies (Marushchak, 2012). Researchers, despite the specifics of the disclosure of this issue, agree that the student's reflective position is a key component of the formation of their professional readiness. A similar position is reflected in the work of the authors who describe the model of higher professional education (Ganieva et al., 2014). Works that reveal the didactic potential of mathematics in the formation of students' reflective position (Feklushkina, 2011) are of particular interest to our research. The author notes that the possibility of interaction (both full-time and virtual) and the ability to visualize educational material should be considered key techniques which activate the mechanisms of reflection in the process of teaching mathematics. It has determined the importance of disclosing the didactic potential of information and communication technologies in the process of forming a reflective position.

Considering the last aspect, we note that in the works of researchers, it is more open through the prism of individualization. So, for example, Krasilnikova (2009) proves the relationship between the ability to take into account individual characteristics and the level of motivation and self-organization of students. It is especially important while studying mathematics, since students with different levels of training and individual-personal characteristics require different amount of time to perceive and understand information presented in alphanumeric and graphical forms. According to Sokolova and Kabanov (2003), the ability to take cognitive styles (styles of perception and processing of information) has a significant impact on the effectiveness of the educational process. It is explained by the fact that the knowledge of the leading channel of perception of information and the adaptation of material to the individual and personal characteristics of students allows to ensure the state of their psychological and physical comfort. Consequently, it has a direct effect on the formation of a reflective position. In addition, it is proved that the presentation of educational information, taking into account the functional specialization of the cerebral hemispheres, is one of pedagogical conditions for the differentiation and individualization of instruction, and, consequently, leads to its improvement. A similar position was outlined by Frolov (2009). Investigating the influence of technical means of teaching on the process of perception of information and its comprehension, he comes to the conclusion that new technologies not only contribute to the intensification of the educational process, but also have a significant influence on the formation and assimilation of concepts and inferences, the establishment of cause and effect relationships, etc. We believe that this idea is especially important in the organization of studying mathematics at university. In addition to it, the influence of information and communication technologies on the process of forming students' reflective position is provided and maintained by the user-friendly interface. Userfriendly interface is not only convenient navigation for users, but also allows to vary the amount of information presented, its placement, font and color design; allows to use interactive and multimedia objects. It becomes possible due to the implementation of such properties of information and communication technologies as multimedia, virtuality, openness, adaptability and manufacturability.

It should be emphasized that the use of information and communication technologies in the teaching of mathematics contributes to the formation of individual educational technology of students. The problem of the formation of individual educational trajectories is reflected in the works of Khutorskoy (2010), Yakimanskaya (2004), etc. Researchers distinguish various approaches to the definition of the essence of the concept. So, Khutorskoy (2010), defines it as a personal way of realizing the personal potential. A number of researchers characterize both the process and the result of the student's individual choice of the content, level and path of education through the exercise of choice. In psychological and pedagogical works, two directions of choice are distinguished: horizontal and vertical. Horizontal direction determines the choice of content, forms of organization of educational activities. Vertical direction provides the choice of the optimal level of education. Osipova (2013) emphasize that choice is an action that gives a focus to the whole activity.

Summarizing the above said, we conclude that most of the sources devoted to the subject describe either generalized theories on the formation of students' reflective position or extremely narrowly specialized questions 


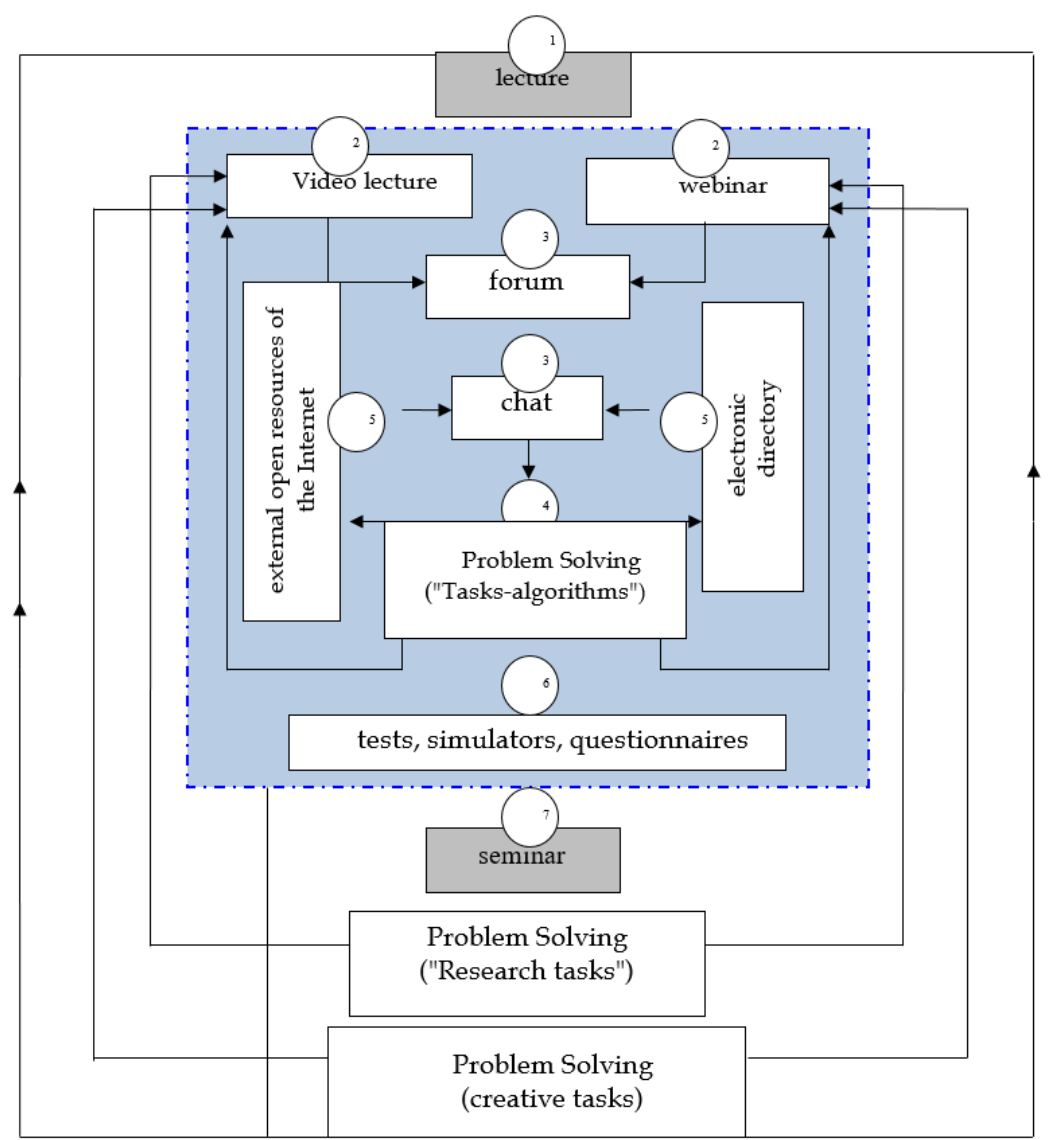

Figure 1. Scheme of the organization of educational and cognitive activity of students in the process of studying math at university by means of information and communication technologies

in the process of teaching mathematics by means of information and communication technologies. This approach actualizes the task of developing methodological support for the formation of the reflective position of university students by means of information and communication technologies in the process of studying mathematics.

\section{MATERIALS AND METHODS}

\section{Designing a Methodical System for Teaching Mathematics with the Didactic Potential of Information and Communication Technologies}

The basis of designing a methodological system for teaching mathematics is the following principles: system, technological, manageability and integrativity. The methodological system of teaching mathematics includes interrelated components (target, content, technological) that determine the logic of interaction between subjects of the educational process. At the first stage, we determined the theoretical basis for designing a methodical system, taking into account the specifics of the mathematical preparation of students. The second stage included developing of the content of the methodical system, the task system was adjusted to reflect the focus - forming students' reflective position. At the third stage we developed the technological toolkit taking into account its didactic potential, for expanding forms and structure of interaction between subjects of the educational process.

We structured the stages of interaction in the form of the organization of educational and cognitive activity (Figure 1). At the same time, it should be noted that the logic of passing the stages for the majority of students is not consistent due to individual and personal characteristics, and it can be cyclical. The logic of the organization of educational and cognitive activities of students, taking into account the selected stages is presented in Table 1. In particular, it is necessary to turn to the first and third stages for the implementation of the fourth stage. This return is necessary in order to update the existing methods of solving problems, as well as to consider theoretical issues that caused the greatest difficulties for students. The most difficult and key sixth stage requires the assimilation and systematization of the information received. Therefore, it updates the transition from the fourth to the third, the second and the first stages. The fifth stage can be right after the first to obtain the necessary information for the formation of individual educational trajectories. 
Table 1. The logic of the organization of educational and cognitive activity of students while studying teaching mathematics by means of information and communication technologies

\begin{tabular}{|c|c|c|c|c|c|}
\hline $\begin{array}{l}\text { No } \\
\text { of } \\
\text { stage }\end{array}$ & Content & $\begin{array}{l}\text { Form of the } \\
\text { organization of } \\
\text { educational and } \\
\text { cognitive activity }\end{array}$ & Description & $\begin{array}{l}\text { Leading } \\
\text { type of } \\
\text { interaction }\end{array}$ & $\begin{array}{l}\text { Realization of possibilities of } \\
\text { information and communication } \\
\text { technologies }\end{array}$ \\
\hline 1 & $\begin{array}{l}\text { presentation of new } \\
\text { material; }\end{array}$ & lecture & $\begin{array}{l}\text { formulation of problematic questions, } \\
\text { search for answers which allow to } \\
\text { identify contradictions and bring to the } \\
\text { solution of certain class of problems } \\
\text { using a mathematical apparatus; the } \\
\text { main theoretical information of the } \\
\text { course; }\end{array}$ & $\begin{array}{l}\text { full-time, } \\
\text { virtual }\end{array}$ & $\begin{array}{l}\text { integration of the content of } \\
\text { mathematics with elements of } \\
\text { professional knowledge, based on the } \\
\text { generality of the studied concepts, their } \\
\text { interdisciplinary connections; methods, } \\
\text { forms and means of teaching; providing } \\
\text { continuous pedagogical support for the } \\
\text { class and extracurricular work of students; }\end{array}$ \\
\hline 2 & $\begin{array}{l}\text { actualization of the } \\
\text { material considered } \\
\text { in the previous } \\
\text { lesson, } \\
\text { systematization of } \\
\text { knowledge, joint } \\
\text { search for solutions } \\
\text { to problem situations; }\end{array}$ & $\begin{array}{l}\text { Video lecture, } \\
\text { problematic } \\
\text { (discussion) } \\
\text { webinar }\end{array}$ & $\begin{array}{l}\text { realized through a specially organized } \\
\text { dialogue, the above-mentioned problem } \\
\text { situations are solved, a demonstration of } \\
\text { key functions and the scope of the } \\
\text { objects under study are realized, causal } \\
\text { relationships are established with } \\
\text { previously studied topics; }\end{array}$ & virtual & $\begin{array}{l}\text { integration of the content of } \\
\text { mathematics with elements of } \\
\text { professional knowledge, based on the } \\
\text { generality of the concepts, their } \\
\text { intersubject connections; methods, forms } \\
\text { and means of teaching; }\end{array}$ \\
\hline 3 & $\begin{array}{l}\text { joint discussion of d } \\
\text { hypotheses, complex } \\
\text { issues; }\end{array}$ & $\begin{array}{l}\text { Forum } \\
\text { Chat }\end{array}$ & $\begin{array}{l}\text { organized by solving two main tasks: } \\
\text { providing assistance in mastering a } \\
\text { certain method of solving problems or } \\
\text { working on theoretical material } \\
\text { (consulting chat); joint discussion of } \\
\text { problem issues (problem forum); }\end{array}$ & virtual & $\begin{array}{l}\text { implementation of operational feedback; } \\
\text { providing continuous pedagogical } \\
\text { support for the class and extracurricular } \\
\text { work of students; }\end{array}$ \\
\hline 4 & $\begin{array}{l}\text { solving problems of } \\
\text { the first level of } \\
\text { complexity ("tasks- } \\
\text { algorithms"); }\end{array}$ & $\begin{array}{l}\text { Independent work } \\
\text { - solving problems } \\
\text { (problem- } \\
\text { algorithms) }\end{array}$ & $\begin{array}{l}\text { solution of problems of the first level of } \\
\text { complexity aimed to reproduce rules, } \\
\text { formulas, actions performed on the } \\
\text { model (tasks of the reproductive level), } \\
\text { formation of skills to apply in practice } \\
\text { the techniques of logical reasoning and } \\
\text { evidence; }\end{array}$ & combined & $\begin{array}{l}\text { taking into account of } \\
\text { psychophysiological features and } \\
\text { individual characteristics of students; } \\
\text { creation of simulating situations (success } \\
\text { situations, introduction of elements of } \\
\text { competitiveness, etc.); }\end{array}$ \\
\hline 5 & $\begin{array}{l}\text { on-line test, } \\
\text { diagnostics, work } \\
\text { with simulators; }\end{array}$ & $\begin{array}{l}\text { work with } \\
\text { electronic } \\
\text { reference book, } \\
\text { glossary, external } \\
\text { Internet resources, }\end{array}$ & $\begin{array}{l}\text { work is carried out with electronic } \\
\text { resources in order to systemize } \\
\text { knowledge and fasten skills of the } \\
\text { decision of problems, diagnostics for } \\
\text { revealing of individually-personal } \\
\text { features and formation of individual } \\
\text { educational trajectories at the } \\
\text { subsequent stages of training; }\end{array}$ & $\begin{array}{l}\text { Virtual, } \\
\text { combined }\end{array}$ & $\begin{array}{l}\text { taking into account psychophysiological } \\
\text { features and individual characteristics of } \\
\text { students; } \\
\text { creation of simulating situations (success } \\
\text { situations, introduction of elements of } \\
\text { competitiveness, etc.); } \\
\text { providing an atmosphere of cooperation } \\
\text { and dialogue; }\end{array}$ \\
\hline 6 & $\begin{array}{l}\text { solving problems of } \\
\text { the second and third } \\
\text { level of complexity } \\
\text { ("research tasks", } \\
\text { creative tasks); }\end{array}$ & $\begin{array}{l}\text { seminar } \\
\text { (practical lesson) }\end{array}$ & $\begin{array}{l}\text { carried out in order to reveal "gaps" in } \\
\text { the knowledge received at the previous } \\
\text { stages, check the formation of skills in } \\
\text { solving problems of reproductive level; } \\
\text { conditions are created for the individual } \\
\text { work of each student with the aim to } \\
\text { form analytical and research capabilities, } \\
\text { skills of modeling processes, interpreting } \\
\text { and evaluating data; }\end{array}$ & $\begin{array}{l}\text { Full-time, } \\
\text { combined }\end{array}$ & $\begin{array}{l}\text { ensuring an atmosphere of cooperation } \\
\text { and dialogue; } \\
\text { implementation of operational feedback; } \\
\text { providing continuous pedagogical } \\
\text { support for the class and extracurricular } \\
\text { work of students. }\end{array}$ \\
\hline
\end{tabular}

The possibility of choice and non-linear nature of the presentation of the teaching material provide the opportunity for studying the course taking into account individual and personal characteristics of students, and, consequently, contribute to the formation of students' reflective position. Strict sequence of the stages from the sixth to the first occurs on the basis of the logic of studying the selected thematic lines of discipline. The presented stages assume the use of individual, paired and collective forms of education.

The basic ideas in the development of a methodical system for teaching mathematics by means of information and communication technologies are the considered technological basis, the specifics of its content, the step-by-step structure of the organization of educational and cognitive activity of students and possible schemes of interaction within it. The concept of "methodology" can be considered as a set of ordered knowledge about the principles, content, methods, means and forms of organization of educational and cognitive activities. This idea was the main one during the development of the stages of the methodology for forming students' reflective position through information and communication technologies. 


\section{RESULTS}

\section{Diagnosis of the Level of Formation of Students' Reflective Position}

Experimental work was carried out on the basis of the Federal State Budget Educational Institution of Higher Education "Vyatka State University" by conducting an experimental teaching of mathematics for students of the chemical and electrical faculties (429 people).

Theoretical interpretation of the concept "reflexive position" was crucial in the choice and implementation of diagnostic techniques aimed to reveal the level of formation of students' reflective position. We explored such parameters as self-organization and reflexive skills of students. This position was justified by the fact that the effectiveness of educational and cognitive activities of students is interrelated with the level of their selforganization. The following task can be singled out as a priority one to be solved in this direction: to form a completely conscious and quite complex action of organizing the time of life, namely: the semantic planning allocation of goals, subgoals, tasks of one's own activity in terms of their semantic significance for the individual; ordering them according to their importance; current control of the order of tasks to be solved, taking into account the pace, rhythm, time spent on all tasks and goals; probabilistic prediction - correlation of immediate and remote tasks in the time perspective of the day, week, month, etc. At the same time, researchers point out that "the action of organizing the time of life" is inseparable from the concept of "self-organization", "self-determination", "selfanalysis", "reflection".

In order to study the level of self-organization of students, we used Ishkov's (2004) questionnaire "Diagnostics of the features of self-organization." In the course of the study we obtained the following data: the overwhelming majority of students demonstrated a low level of self-organization skills; the average level was revealed in $35.5 \%$ of respondents; a high level - in $25.2 \%$ of the total number of students.

Note that students with a low level of self-organization demonstrate an unconscious choice of a profession, a weak motivation for activity, a lack of systematic and consistent in the organization of educational and cognitive activities, low self-esteem in achieving the goal, lack of reflexivity. Students of the second group are characterized by an informed choice of profession, formed skills of planning activities and analyzing its results. At the same time, they have difficulties in exercising self-esteem and reflection. Students with a high level of self-organization are characterized by the following indicators: an adequate choice of profession, high motivation, pronounced volitional characteristics, sufficiently high self-esteem, purposefulness, organization, high performance, self-confidence, formed reflection skills.

The data obtained during the diagnosis were significant for us. First of all, it is due to the interdependence of self-organization with reflexive processes. According to a number of researchers, the formation and development of reflection among students will help them to enter the reflexive position of educational and cognitive activity, ensure the inclusion of one's own " $\mathrm{I}$ " in this process. In this aspect, the authors consider the reflective position as the situation when the subject enters a new external position with respect to the activity performed. For this purpose, in the process of preparation, it is advisable to use special assignments and include students in joint activities aimed to form students' skills of self-organization and self-control in educational and cognitive activity.

Thus, taking into account the fact that an important structural element of self-organization is the level of the formation of a reflective position, let's analyze it. Therefore, we used Karpov's (2003) technique. In the course of the study, we obtained the following data: $31.5 \%$ of the respondents showed a low level of formation of reflective skills; $48.3 \%$ of students - intermediate; $20,2 \%$ of respondents - high.

The analysis of data, obtained by us during two diagnostic methods, actualized the search for a solution to the problem of forming students' reflective position. In order to do it, we designed a methodical system for teaching mathematics, taking into account the didactic potential of information and communication technologies.

\section{Methodology for Forming Students' Reflective Position In The Process of Teaching Mathematics Using Information and Communication Technologies}

The purpose of the methodology for forming students' reflective position in the process of teaching mathematics using information and communication technologies is detailed by the following tasks: identification of the level of motivation to study mathematics and getting a future profession; definition of the "initial" level of mathematical preparation of students; identification of "barrier" mechanisms for studying mathematics; definition of the type of cognitive modality of individual; diagnosis of the formation of skills of self-organization, self-control and reflexive skills.

The developed methodology is represented by three modules: information, design and reflexive ones. 
Table 2. Estimated data on EG and CG for the application of the multifunctional Fisher test

\begin{tabular}{lccc}
\hline \multirow{2}{*}{ Groups } & «There is an effect» & «There is no effect» & \multirow{2}{*}{ Total } \\
\cline { 2 - 4 } & $\begin{array}{c}\text { Number of students (\%) } \\
\text { (high and medium level) }\end{array}$ & $\begin{array}{c}\text { Number of students (\%) } \\
\text { (low level) }\end{array}$ & \\
\hline The first sample $(E G)$ & $143(70,1 \%)$ & $61(29,9 \%)$ & $204(100 \%)$ \\
\hline The second sample $(C G)$ & $151(67,1 \%)$ & $74(32,2 \%)$ & $225(100 \%)$ \\
\hline
\end{tabular}

The information module aims to inform students about the specifics of organizing their own activities and planning time. This module contains tasks aimed to form students' self-organization skills. The design module includes practice-oriented tasks, solutions of which require the application of both a mathematical apparatus and knowledge of professional disciplines. This block aims to develop logical and reflective thinking of students. Reflexive block provides formation and correction of students' reflective position; self-analysis and selfdevelopment of the individual.

The developed technique assumes full-time and virtual interaction of subjects of educational process. Through the use of information and communication technologies, we conducted such webinars within the information module as: Information Crystals (Effective Information Processing Techniques), Secrets of Time Management (an information module of the methodology); in the framework of the design module: "I want to be an engineer, let them teach me!", "Kaleidoscope of scientific discoveries"; within the framework of the reflexive module: "Funny Mathematics"; "The engineer of the third millennium is an engineer of the future, what is he like?".

Let us note that in addition to the theoretical part, students were offered a system of practical tasks, the discussion of which took place within the framework of organized chats ("Mathematics (physics, chemistry) for the engineer: myth and reality"), round tables "Heritage of the past" (about great inventions, discoveries and scientists) with the help of didactic techniques (synquine, constellation - engineer, wish tree, five fingers, "fish-born" "thick" and "delicate questions"). It should be emphasized that the specifics of these methods and forms of training were determined by the specifics of the direction of student preparation.

\section{The Results of Approbation of the Methodology for Forming Students' Reflective Position While Studying Mathematics}

To justify the effectiveness of the developed methodology, we formed a control and experimental group. In conclusion, at the final stage of the experiment, after approbation of all stages of the developed technique in the experimental group, we conducted a final diagnosis in order to identify the dynamics in the process of forming students' reflective position by means of information and communication technologies while studying mathematics.

In order to do it, we verified and justified the homogeneity of samples of the control and experimental groups using the multifunctional Fisher test (Table 2).

Let's find $\varphi_{1}$ and $\varphi_{2}$, corresponding to the percentage of the "effect" in each group: $\varphi_{1}=1.984 ; \varphi_{2}=1.920$. To do this, we use the table "Angle values $\varphi=2 \arcsin \sqrt{p}$ (in radians) for different percentages" [12].

Let's calculate the empirical value of the criterion:

We find the critical values from the table "Levels of statistical significance of different values of the Fisher test » $\varphi_{\text {кpum }}^{*}=\left\{\begin{array}{l}1.64, p=0.05 \\ 2.31, p=0.01\end{array}\right.$.

Let us compare the empirical value $\varphi_{\ni \mathcal{M} n}^{*}$ with the critical $\varphi_{\kappa p u m}^{*}$. To do this, we construct an "axis of significance":

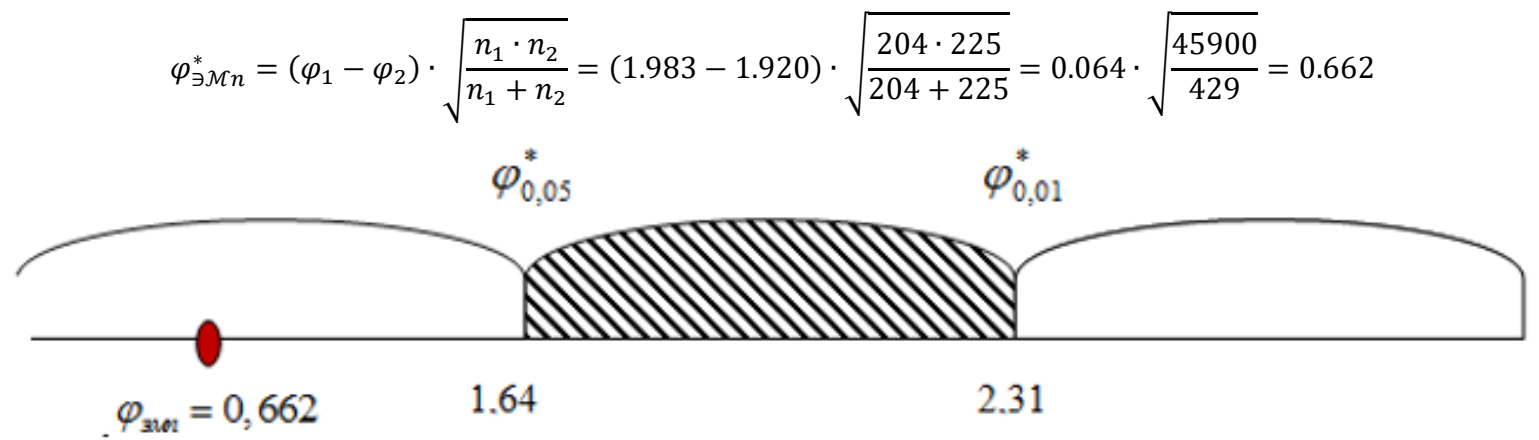

Since $\varphi_{\ni \mathcal{M} n}$ fell into the zone of "insignificance of differences," we believe that at $5 \%$ level of significance $\left.t\right]$ :e are no grounds for rejecting the hypothesis $H_{0}$. It means that at the $5 \%$ level of significance, the proportio of 
Table 3. Calculation of the parameters of the angular Fisher transformation

\begin{tabular}{|c|c|c|c|}
\hline & «There is an effect» & «There is no effect» & \\
\hline Groups & $\begin{array}{l}\text { Number of students (\%) } \\
\text { (high and medium level) }\end{array}$ & $\begin{array}{c}\text { Number of students (\%) } \\
\text { (low level) }\end{array}$ & Total \\
\hline The first sample (EG) & $164(80,4 \%)$ & $40(19,6 \%)$ & $204(100 \%)$ \\
\hline The second sample (CG) & $159(70,7 \%)$ & 66 (29,3\%) & $225(100 \%)$ \\
\hline
\end{tabular}

students "with effect" in the first sample (control group) is not greater than in the second sample (the experimental group). Consequently, with a confidence of 0.95 , it can be asserted that there are no statistically significant differences between the percentages of the two samples in terms of the level of formation of the reflexive position at the beginning of the experimental work. Thus, the foregoing theoretical justification allows to conclude that the samples of the control and experimental groups are homogeneous.

Analyzing the level of the formation of reflexive skills at the initial and control stages of the experiment, we note that the trend has changed in the positive direction, namely: a decrease in the number of students with a low level of this indicator $(19.6 \%)$ and an increase in the number of students with an average $(50.5 \%)$ and a high level $(29.9 \%)$.

We emphasize that the increase in the number of students demonstrating the high and average level of the formation of a reflective position was achieved through the provision of the right to independently choose the trajectory of instruction with its subsequent adjustment; activization of educational and cognitive activity by providing a professional orientation of education, use of information and communication technologies. We shall calculate the parameters of the angular Fisher transformation for a reflexive criterion (Table 3).

The percentage of students with a high level of manifestation of the test criterion is: $80.4 \%$ in the experimental group, $70.7 \%$ in the control group. The values $\varphi_{1}$ and $\varphi_{2}$, corresponding to the percentages in each group were found from the table: 2.224 and 1.998. The empirical value of the criterion is:

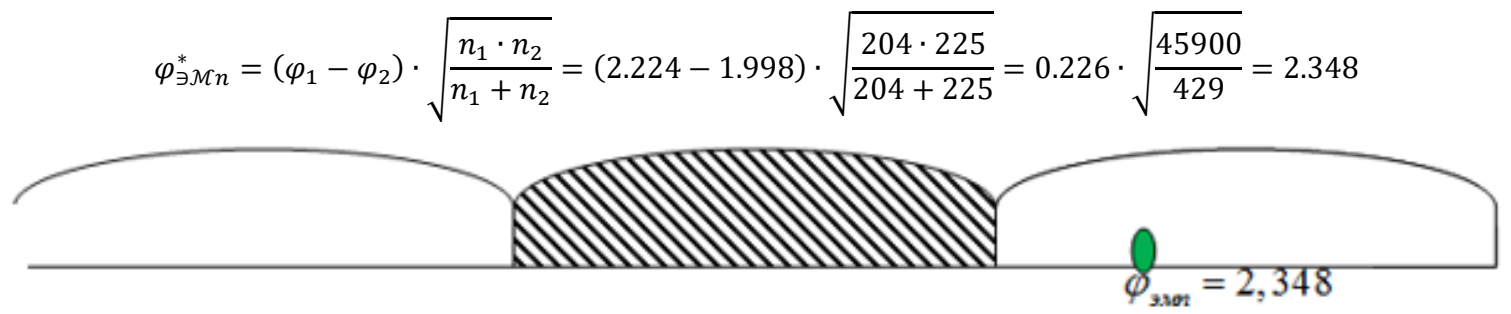

\section{Zone of significance of differences}

Since $\varphi_{\ni \mathcal{M} n}^{*}$ fell into the zone of "significance of differences", we can assert at the $5 \%$ level of significance that at the end of the experimental work in the experimental and control groups there are reliable differences in the percentage of students with an average and high level of reflexive position.

\section{DISCUSSIONS}

Today in pedagogical science, as well as in domestic and foreign educational practices, the aim of various works is to solve a range of problems existing in the organization and implementation of mathematical training at university. We considered one of the aspects of the process of mathematical preparation, namely: the formation of students' reflective position while studying mathematics. Information and communication technologies were the leading didactic means. Analysis of scientific and methodological literature, as well as our own teaching experience allowed to highlight the significant pedagogical potential of the technologies in forming students' reflective position: motivational-adaptive; subjective, integrative; managerial. At the same time, it should be noted that, despite the positive impact of information and communication technologies on the training process in general, there are certain difficulties.

Among the key difficulties are: elaboration of methodological materials, level of computer and information literacy of teachers and students, "limiting of social contacts," the gap between knowledge and experience in cognition, illusion of free personal goal-setting and choice, virtual dependence, reliability of software and hardware, its functionality, etc. These aspects allow to formulate promising lines for improving the developed methodology, in particular, the detailed method forms, methods, the organization of educational and cognitive activity of students, taking into account the levels of differentiation and the "initial" amount of knowledge of students. We believe that this, in turn, will improve the effectiveness of the developed methodology and its results. 


\section{CONCLUSION}

In the process of analyzing different points of view on the problem of forming students' reflective position through the means of information and communication technologies, there were developed and introduced into educational practice methodical approaches based on the didactic capabilities of these technologies: motivationaladaptive; subjective, integrative; management resources.

The approbation contributed to the concretization of the methodological system of teaching mathematics at university, supplemented by such forms of work as a webinar, virtual excursion, chat, etc.

The realization of the ideas of the personality-activity approach is ensured by the recognition of the priority of individuality and self-worth of each student, the maximum appeal to his individual experience, the need for selforganization, self-determination and self-development, the design of general conceptual provisions of the theory of activity in the pedagogical area; analysis of the results of the training in the form of an integrative system of actions.

Our research has a prognostic value, as it creates real prerequisites for further scientific research in the study of the specifics of the introduction of information and communication technologies in educational practice, taking into account the development of information and technological characteristics of modern society, the flexibility and changing orientations of Federal state educational standards, the sophistication of science-intensive and technological spheres of production.

\section{ACKNOWLEDGEMENT}

The study was carried out with the financial support of the State Assignment of The Ministry of Education and Science of the Russian Federation "Teacher Training Technologies in a Classical University Environment", the project № 27.9412.2017/8.9.

\section{REFERENCES}

Bagdai, E. V. (2007). Formation of a reflective position of a student in the process of studying humanitarian disciplines (PhD Thesis). Kirov: RSL OD.

Baytak, A., Akbiyik, C., \& Usak, M. (2012). Parents' Perception over Use of ICT in Education. Technics Technologies Education Management-TTEM, 7(3), 1158-1167.

Biktagirova, G. F., \& Valeeva, R. A. (2014). Development of the teachers' pedagogical reflection. Life Science Journal, 11(9), 60-72.

Dede, C. (2008). Theoretical Perspectives Influencing the Use of Information Technology in Teaching and Learning. International Handbook of Information Technology in Primary and Secondary Education, 20, 43-62. https://doi.org/10.1007/978-0-387-73315-9_3

Feklushkina, A. V. (2011). The formation of reflexive activity of students in the process of studying mathematics. Moscow: Prosveshcheniye.

Frolov, I. N. (2009). E-learning as a form of organization of the educational process in the 21st century. Informatics and education, 2, 109-110.

Ganieva, Y. N., Azitova, G. S., Chernova, Y. A., Yakovleva, I. G., Shaidullina, A. R., \& Sadovaya, V. V. (2014). Model of High School Students Professional Education. Life Science Journal, 11(8), 1097-8135.

Geiger, V., Calder, N., Tan, H., Loong, E., Miller, J., \& Larkin, K. (2016). Transformations of Teaching and Learning Through Digital Technologies. Singapore: Springer. https:/ / doi.org/10.1007/978-981-10-1419-2_13

Ishkov, A. D. (2004). Educational activity of the student: psychological factors of success. Moscow: ASV Publ.

Karpov, A. V. (2003). Reflectivity as a psychic property and the technique of its diagnosis. Psychological journal, 24(5), 45-57.

Khusainova, R. M., Chirkina, S. E., \& Gabdrakhmanova, R. G. (2015). The Role of the Reflective Activity of Students in Individual Educational Traectory. Review of European Studies,7(5), 146-152. https://doi.org/10.5539/res.v7n5p146

Khutorskoy, A. V. (2010). Pedagogical Innovation: Textbook for students of higher education institutions. Moscow: Academy Publ.

Krasilnikova, V. A. (2009). Theory and technology of computer training and testing. Moscow: The House of Pedagogy.

Kubiatko, M., Usak, M., Yilmaz, K., \& Tasar, M. F. (2010). A Cross-National Study of Czech and Turkish University Students' Attitudes towards ICT Used in Science Subjects. Journal of Baltic Science Education, 9(2), 119-134. 
Kvon, G. M., Lushchik, I. V., Karpenko, M. A., Zaitseva, N.A., Kulkov, A.A., Galushkin, A.A., \& Yakupova, N.M. (2017). Regional investment policy: Analysis and assessment of the investment environment state. Eurasian Journal of Analytical Chemistry, 12(5), 835-853. https:/ / doi.org/10.12973/ ejac.2017.00215a

Kvon, G. M., Prokopyev, A. I., Shestak, V. A., Ivanova, S. A., \& Vodenko, K. V. (2018). Energy saving projects as energy security factors. International Journal of Energy Economics and Policy, 8(6), 155-160. https://doi.org/10.32479/ijeep.7143

Lin, X., Hmelo, C., \& Kinzer, C. K. (1999). Designing technology to support reflection. Educational Technology Research and Development, 47(3), 43-62. https:/ / doi.org/10.1007/BF02299633

Marushchak, I. P. (2012). Pedagogical support of the process of forming reflective position of university students through interactive teaching technologies (PhD Thesis). Tver.

Nelson, B. C. (2007). Exploring the Use of Individualize, Reflective Guidance In an Educational Multi-User Virtual Environment. Journal of Science Education and Technology, 16(1), 83-97. https:/ / doi.org/10.1007/s10956-0069039-x

Oborsky, A. Y., Chistyakov, A. A., Prokopyev, A. I., Nikolyukin, S. V., Chistyakov K. A., \& Tararina L. I. (2018). The national mentality in the history of philosophy. XLinguae, 11(3), 158-165. https:/ / doi.org/10.18355/XL.2018.11.03.15

Osipova, S. I. (2013). Designing a student of an individual educational trajectory in the context of the informatization of education. Moscow: INFRA.

Rath, A. (2010). Reflective Practice as Conscious Geometry: Portfolios as a Tool for Sponsoring, Scaffolding and Assessing Reflective Inquiry in Learning to Teach. Boston: Springer.

Ryan, M. (2015). Sustainable Pedagogical Change for Embedding Reflective Learning Across Higher Education Programs. Teaching Reflective Learning in Higher Education, 1, 213-227. https:// doi.org/10.1007/978-3-31909271-3_15

Semenov, I. N. (2011). Reflective consciousness and the intuitive creative act. Psychology questions, 6, 152-155.

Sokolova, I. Yu., \& Kabanov, G. P. (2003). The quality of training specialists at a technical college and technology training: a manual for teachers, graduate students, undergraduates. Tomsk: TSPU.

Wang, J. R., \& Lin, S. W. (2008). Examining Reflective Thinking: A Study of Changes in Methods Students' Conceptions and Understandings of Inquiry Teaching. International Journal of Science and Mathematics Education, 6(3), 459-479. https:/ / doi.org/10.1007/s10763-007-9085-8

Wulfov, B. Z., \& Harkin, V. N. (1995) Pedagogy of reflection. Moscow: IChP "Publisher Master".

Yakimanskaya, I. S. (2004). Psychological foundations of mathematical education: Textbook for students of higher education institutions. Moscow: Academy Publ.

Yuen L. L. (2011). A comparison of students' reflective thinking across different years in a problem-based learning environment. Instructional Science, 38(2), 171-188. https:/ / doi.org/10.1007/s11251-009-9123-8

Zaitseva, N. A., Larionova, A. A., Gornostaeva, Zh. V., Malinina, O. Yu., Povalayeva, V. A., Vasenev, S. L., Skrynnikova, I. A., \& Ersozlu, A. (2017). Elaboration of the methodology for assessing the development of managerial competences in university students taught with the use of case-technologies. Eurasia Journal of Mathematics, Science and Technology Education, 13(11), 7339-7351. https:/ / doi.org/10.12973/ejmste/79609

\section{http://www.ejmste.com}

